\title{
Heredera de Pedro Madrigal: María de Quiñones, impresora de ingenios áureos
}

\author{
Herdeira da Pedro Madrigal: María de Quiñones, \\ impressora da Idade de Ouro \\ Heiress of Pedro Madrigal: María de Quiñones, \\ printer of the Golden Age
}

Davinia Rodríguez Ortega*

Resumen: El presente artículo aborda la historia de la imprenta fundada por Pedro Madrigal en 1585 en Madrid, después de dejar su taller en Salamanca. Tras la muerte del editor, le sucedieron en el manejo de las prensas su viuda, María de Rodríguez, su "hijo" Pedro Madrigal, Juan de la Cuesta y María de Quiñones. Esta última gozó de una privilegiada situación de negocio que aprovechó junto al librero Pedro Coello, para imprimir comedias tras la prohibición que concluyó en 1634. De este modo, de su imprenta salieron partes de comedias de los grandes autores áureos como Tirso de Molina, Calderón de la Barca o Lope de Vega, entre otros.

Palabras clave: María de Quiñones; Pedro Madrigal; imprenta; partes de comedias; Calderón de la Barca

Resumo: Este artigo discute a história da imprensa fundada por Pedro Madrigal em 1585 em Madrid, depois de deixar sua oficina em Salamanca. Após a morte do editor, sucederam-no no manejo das prensas sua viúva, Maria Rodriguez, seu "filho" Pedro Madrigal, Juan de la Cuesta e Maria de Quiñones. Esta última aproveitou uma oportunidade privilegiada de negócios e levou consigo o livreiro Pedro Coello para imprimir comédias após o fim da proibição, em 1634. Assim, da sua impressão surgiram peças de comédias de grandes autores da Idade de Ouro como Tirso de Molina, Calderon de la Barca e Lope de Vega, entre outros.

Palavras-chave: María de Quiñones; Pedro Madrigal; imprensa; peças de comédia; Calderón de la Barca

\footnotetext{
*Profesora en la Universidad Internacional de La Rioja (UNIR, España).<davinia.rodriguez.ort@ gmail.com> <dados biográficos/biographic data $>$
} 


\begin{abstract}
This paper deals with the history of the press founded by Pedro Madrigal in 1585 in Madrid, after he left his workshop in Salamanca. After the death of the editor, several printers followed his steps in the studio: his widow, María de Rodríguez; his supposed "son" Pedro Madrigal; Juan de la Cuesta and finally, María de Quiñones. This last one enjoyed a privileged chance for business and took advantage of it along with the bookseller Pedro Coello, so they printed several parts of comedies after the prohibition finished in 1634. Therefore, the studio managed by Quiñones released comedies written by great authors of the Golden Age such as Tirso de Molina, Calderón de la Barca o Lope de Vega, amongst others.
\end{abstract}

Keywords: María de Quiñones; Pedro Madrigal; press; parts of comedies; Calderón de la Barca

\title{
Introducción
}

La protagonista de este estudio, María de Quiñones, fue una impresora madrileña en activo desde aproximadamente 1633 hasta 1666; como en otros muchos ejemplos, se hizo cargo del taller de su esposo, tras la desaparición de este, y se volvió a casar con un miembro del gremio con la intención de perpetuar el negocio editorial. En el caso de Quiñones, la genealogía de su imprenta es extensa: Pedro Madrigal (padre), su viuda María Rodríguez de Ribalde, Juan Íñiguez de Lequerica (esposo de la viuda), Pedro Madrigal (hijo), Juan de la Cuesta, y la mujer de los dos últimos impresores, María de Quiñones. El 1666 traspasa su taller a Melchor Alegre, al que a su vez sucederá su esposa Catalina Gómez, ejerciendo la impresión hasta su fallecimiento en 1691.

Si el aspecto de la imprenta española y la industria del libro ha sido ampliamente estudiado, tanto en datos sobre impresores como sobre casos particulares de talleres en distintas ciudades de la península

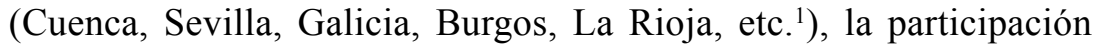
femenina en este negocio tan importante durante el Siglo de Oro apenas cuenta con unos pocos estudios. De este modo, podemos destacar los trabajos de Fernández Vega (2004) sobre la valenciana Jerónima de Gales; Griffin (1993) en torno a Brígida Maldonado ${ }^{2}$ en Sevilla; Pedraza

\footnotetext{
${ }^{1}$ Un completo documento recopilador se puede encontrar en la página de la BNE dedicada a "Mujeres impresoras". Disponible en: <http://www.bne.es/es/Micrositios/Guias/Mujeres Impresoras/Siglos_XVI-XVII/Bibliografia/>. Acesso em: 05 abril 2016. Asimismo, las diferentes secciones de esta web ofrecen información sobre el mismo tema en diferentes periodos: siglos XVI-XVII, XVII y XIX, panorama que se completa con una introducción y una bibliografía general.

2 Según reza el título del artículo, es la viuda de Juan Cromberger, heredero del importante patrimonio de su padre Jacobo y fundador de la primera imprenta en América; Griffin también ha publicado una monografía sobre la trayectoria de este taller (1991).
} 
Gracia $^{3}$ (2009a) alrededor de Juana Millán en Zaragoza; Rumeau (1971), quien trata sobre la burgalesa Isabel de Basilea y la alcalaína Juana Martínez de Angulo ${ }^{4}$, estudiada por Vázquez Madruga (2010); todas ellas son impresoras que ejercen su profesión en el siglo $\mathrm{XVI}^{5}$. Respecto a la centuria posterior, en pleno periodo aurisecular, el único trabajo encontrado trata sobre la impresora baezana Mariana Montoya, escrito por Sánchez Cobos (2004); como consecuencia, es fácil suponer que el camino aún por recorrer es amplio, además de necesario, para lograr poner en valor el papel de estas mujeres que, con escasa o nula formación, lograron sacar adelante los talleres tipográficos heredados de sus padres o esposos.

\section{La imprenta de Pedro Madrigal: orígenes y fundación}

La trayectoria, tanto sentimental como profesional, de María de Quiñones aparece estrechamente ligada a la imprenta fundada por Pedro Madrigal en $1586^{6}$, acerca de la cual afirma Pérez Pastor, sin aportar muchos más datos que fue: "Una de las mejores imprentas de Madrid [...]. Imprimió Madrigal muchos y excelentes libros, tanto latinos como castellanos, hasta el año 1594, en cuyo año debió morir..." (PÉREZ PASTOR, 1891, p. XXVI). El impresor Madrigal, quien tenía un taller en Salamanca, mudó sus prensas hasta la madrileña calle de Atocha:

(...) con los materiales del taller de Domingo de Portonariis, que había comprado, se instala Pedro Madrigal en una de las zonas de expansión de la corte, en la calle de Atocha, alquilando una casa que pertenecía a Tomás de Labao, menor, residente en Mallorca, hermano y heredero de Bernardo de Labao (MOLL, $2005 \mathrm{~b}, \mathrm{~s} / \mathrm{p}$.).

\footnotetext{
${ }^{3}$ Este autor también tiene un estudio de cariz genérico sobre la cuestión durante los siglos XVI y XVII (PEDRAZA GARCÍA, 2009b).

4 También existe otro trabajo sobre esta impresora de Cortés y Méndez (1991).

5 Las fechas de publicación de estos trabajos confirman que se trata de una parcela de investigación de incipiente interés.

${ }^{6}$ Esta fecha también es aportada por Pérez Pastor, además de fijar su primera actividad editorial en 1584, sin embargo, Gutiérrez del Caño asevera que imprimió en Madrid entre 1577-1630 (AGULLÓ Y COBO, 1992, p. 178); no es posible confirmar la fecha de inicio de su negocio, aparte del documento que ofrece Pérez Pastor, pero si contradecir que su actividad se extendiera hasta 1630, porque, como veremos a continuación, en esos años le sucedieron su hijo Pedro Madrigal y el oficial del taller, Juan de la Cuesta. Además, de nuevo Pérez Pastor ofrece un documento que atestigua su fallecimiento en 1594 (AGULLÓ Y COBO, 1992, p. 178).
} 
lugar en el que permanecería hasta el cese de la actividad de Quiñones en 1666 y que mantendría el "heredero" Melchor Alegre?. Un importante testimonio sobre los materiales que atesoraba la imprenta de Madrigal es el inventario realizado por su viuda María Rodríguez en 1595 antes de contraer matrimonio con el impresor Íñiguez de Lequerica; el documento nos ofrece la siguiente información:

Contaba María Rodríguez de Rivalde con seis prensas (número importante, como hemos visto), tasadas a 30 dcs. cada una; tres piedras nuevas para ellas ( 8 dcs.), dos ramas grandes y cinco rametas; unas matrices de cursiva de lectura (150 rs.), otras de gran canon, "crudas y por justificar", de texto, de Breviario de romance, de libro de caja, de cursiva de parangona o paladina, de peticanon, $A$ de parangona grande, de Misal de Plantino, de cursiva, de glosa, de atanasia, de romance, de lectura griega..., todas ellas con sus moldes.

Había que añadir 149 arrobas de metal viejo nuevamente fundido, otra fundición de siete suertes o clases de letras, 80 piezas cortadas de historia para Epístolas y Evangelios, viñetas, armas reales, florones, armas papales de diversas Órdenes religiosas, de obispos; un abecedario nuevo en madera, dos cajones con gran número de letras e imágenes, viñetas y letras en cobre y madera.

Todas las letras floridas se conservaban en un escritorio de seis cajones y había otras 36 cajas, suponemos que con otros materiales.

Contaba la imprenta con 24 bancos sobre caballetes, 9 bancos de asiento para la composición, un cargador de papel con su grúa, una mesa con su cajón, 5 bancos grandes y una escalera.

Se relacionan además entre los materiales: 49 tablas de imponer, 11 galeras, 4 divisorios de hierro, 11 galerones, dos ollas de cobre para barniz con sus tapaderas, un moledor con su aderezo de cobre, tres arrobas de trementina y una sierra.

Conservaba también 1.013 pliegos de pergamino escrito (de ellos, 351 grandes y gruesos y 792 delgados, menor "para frasquetas") (AGULLÓ Y COBO, 1992, p. 1-2).

\footnotetext{
7 En la actualidad, este local es la sede de la Sociedad Cervantina donde aún se conserva la prensa de tipos móviles donde se imprimió el Quijote de 1605 por Juan de la Cuesta.

8 Asimismo, en este escrito, se informa de que el nuevo impresor regente no puede despedir a ninguno de los trabajadores sin "causa justa"; parece que la imprenta fundada por Madrigal no solo cuidaba sus impresiones sino también las condiciones de sus trabajadores. El librero Miguel Martínez también realiza este procedimiento tres décadas después, en 1629, al casarse con Catalina de Villada, que suscita mayor interés al haberse realizado en vida del propietario, no tras su muerte (DADSON, 1997, p. 41).
} 


\subsection{Perfección en el oficio}

Por añadidura, encontramos mayor información sobre la actividad editorial de este taller en otros trabajos de investigación; el profuso estudio de Agulló y Cobo nos ofrece testimonio de la riqueza y calidad de la imprenta de Madrigal $^{9}$ desde sus inicios hasta la época de Juan de la Cuesta. En lo respectivo a la calidad de las piezas salidas de sus prensas, hallamos información valiosa en un paratexto ${ }^{10}$ a la edición de Madrigal a los Comentarios de las guerras sucedidas en los Países Bajos, de Bernardino de Mendoza, publicada en 1592; en un texto dirigido expresamente al lector, comenta el editor las dificultades halladas durante el proceso:

He trabajado de poner algunas márgenes en él y hacer una tabla dellas, y de otras cosas notables, para que se pueda con las dos cosas, y división de capítulos, señalados a la margen, hallar con más facilidad lo que se desea leer, siguiendo en esto la impresión francesa que se hizo de este libro en París (AGULLÓ Y COBO, 1992, p. 15) ${ }^{11}$.

De este fragmento se extrae información sobre la preocupación de Madrigal acerca del proceso de lectura de sus impresos, que va más allá del negocio e implica la recepción, la lectura y la fidelidad al texto original.

Mas no se trata esta de una postura aislada en la trayectoria de la imprenta fundada por Pedro Madrigal, sino que sus continuadores pondrán el mismo empeño en el cuidado de sus ediciones. Juan Íñiguez de Lequerica, segundo esposo de María Rodríguez de Ribalde, también aprovechó las páginas previas a su edición de los Sermones funerales en las honras de Felipe II, en la que según describe en la portada "va

\footnotetext{
9 También Moll (2005b) escribió un artículo sobre esta imprenta, pero más centrado en cuestiones inmobiliarias y económicas que editoriales, resulta muy interesante para aprender sobre la fundación y recorrido de un taller esencial en la industria editorial de finales del XVI y principios del XVII, sin embargo excede los límites de este estudio.

${ }^{10}$ Como veremos en la parte final de este trabajo, dedicado al estudio de los impresos fruto de la actividad de María de Quiñones, autores y editores solían utilizar los prólogos o dedicatorias para comentar cuestiones acerca del proceso editorial. Así lo hace Tirso de Molina al quejarse del librero Gabriel de León en la Tercera parte de comedias impresa por Quiñones en 1635.

${ }^{11}$ Según recoge Agulló y Cobo, el prosista aurisecular Liñán y Verdugo menciona también la pericia editorial de Madrigal en los preliminares de su obra Guía y aviso de forasteros; tras ensalzar la labor de los impresores extranjeros Horacio Cardon y Justo Queerbergio, concluye: "también en España se podia 'estimar el cuidado con que los han hecho nuestros naturales, y en nuestros tiempos especialmente en esta Corte Pedro Madrigal y Luis Sánchez, impresor del Rey"'. (AGULLÓ Y COBO, 1992, p. 16)
} 
añadida una tabla muy copiosa para sermones de difuntos particulares y los Evangelios de todo el año", para explicar las razones de su empresa:

Por ser tan dificultoso y tan costoso hacer copias de mano, y tan fácil hacer muchas de una vez en emprenta, me han persuadido muchos religiosos y legos a que imprima los sermones que he recogido, de los que predicaron en las horas (ÍÑIGUEZ DE LEQUERICA, $1601, \mathrm{~s} / \mathrm{p})^{12}$.

Si en el caso de Pedro Madrigal hallábamos los apuros del editor por mejorar el proceso de lectura de sus textos, con Íñiguez de Lequerica el panorama se amplía incluyendo la razón de dicha impresión.

En cualquier caso, el trabajo del impresor va más allá de poner los textos en negro sobre blanco y se involucra por completo en la configuración de los libros y su recepción. Posiblemente, ambos serían conscientes de que si su fama se extendía entre los lectores y libreros madrileños, por su calidad y cuidado, la existencia de su imprenta sería larga y próspera.

Finalmente, es posible acudir al testimonio de Pérez Pastor acerca de la profesionalidad de Juan de la Cuesta en la impresión de las Efemérides generales de los movimientos de los cielos por doce años, "impresas en 1608 por Juan de la Cuesta con unas tablas complicadísimas, cuya impresión fue un verdadero alarde de habilidad y paciencia" (AGULLÓ Y COBO, 1992, p. 16); no obstante, es bastante probable que esta impresión no fuera realizada por Juan de la Cuesta; según atestigua Moll:

El 4 de diciembre de 1607, Juan de la Cuesta se encuentra en Sevilla y ante el notario Pedro Vásquez de Miranda da amplios poderes a su mujer, María de Quiñones, a su suegra, María Rodríguez de Ribalde, y a Jerónimo de Salazar, para regir la imprenta, cobrar lo que se les debiere y actuar en su nombre (MOLL, 2005a, p. 482).

\subsection{Herederos del taller de Madrigal}

Tres figuras masculinas aparecen ligadas a la imprenta fundada por Pedro Madrigal: Juan Íñiguez de Lequerica, Pedro Madrigal (hijo) y Juan de la Cuesta.

\footnotetext{
${ }^{12}$ Se trata, por tanto, de un volumen colectivo que compila y edita Íñiguez de Lequerica, costeado por el librero Varez de Castro.
} 
Íñiguez de Lequerica fue un impresor alcalaíno que se casó en segundas nupcias con María Rodríguez:

El 31 de mayo de 1595, se celebró en la iglesia parroquial de San Sebastián el desposorio del impresor alcalaíno Juan Íñiguez de Lequerica con la viuda de Pedro Madrigal, María Rodríguez de Ribalde, siendo testigos Juan Moreno, Francisco López, librero, Francisco Robles -el librero o el fundidor de tipos-, Francisco Sánchez y Juan Bernal” (MOLL, 2005a, p. 476)

y aunque pasó a ser el impresor del taller de Pedro Madrigal, nunca abandonó su propio negocio. Según afirma Pérez Pastor, falleció en 1599, aunque según asevera Agulló y Cobo su desaparición tendría lugar en 1598, fecha tras la cual el pie de imprenta de las obras sacadas de sus prensas volvió a ser el de María Rodríguez de Ribalde (AGULLÓ Y COBO, 1992, p. 137); pero tras un rastreo de las obras publicadas en el taller entre 1595-1603, encontramos una coincidencia: su pie de imprenta es "En casa de Pedro Madrigal" o "Por la viuda de Pedro Madrigal", sin referencia alguna al editor de Alcalá.

La información disponible acerca de la vida de Pedro Madrigal (hijo) es muy escasa y acerca de su labor editorial no sabemos nada, ya que durante el periodo en que pudo ejercer como responsable del taller la rúbrica era "Herederos/Casa de Pedro Madrigal", que ya se utilizaba en la época de María Rodríguez e Íñiguez de Lequerica y seguiría vigente una vez fallecido el heredero de Madrigal hasta la llegada de Juan de la Cuesta. Moll menciona que existen anotaciones de su actividad en la Hermandad de impresores en 1697-1698, un año después firma un documento en nombre de María Rodríguez de Ribalde, que era analfabeta, y en 1601 se hace cargo de la impresión de un volumen de fray Diego de Yanguas (MOLL, 2005a, p. 478). Hasta aquí alcanzan los datos relativos al heredero de Pedro Madrigal, que siembra las dudas acerca de su origen familiar cuando suscribe: "P." de Madrigal [si firma no tiene el de] ynpresor de libros por sí y por María Rodríguez, su tía" (MOLL, 2005a, p. 478): como consecuencia permanece la duda de si sería realmente hijo de Rodríguez o de un hermano de Pedro Madrigal (padre). Lo que sí parece cierto es que sufriera una muerte prematura ya que María de Quiñones se desposó con Juan de la Cuesta en junio de $1602^{13}$.

${ }_{13}$ Augusto Jurado aporta una copia del certificado del matrimonio, así como de las partidas bautismales de los dos hijos de la pareja. (JURADO, 2007, p. 34-35) 
Según recoge Jurado: “Juan de la Cuesta se casó con María de Quiñones el 26 de junio de 1602, y fueron testigos García Martínez y Francisco de Quiñones" (JURADO, 2007, p. 34). Del fruto de este enlace "nacieron dos hijos: Juan, nacido el 18 de julio de 1606, y que debió morir prematuramente, ya que su segundo hijo al que también llamaron Juan, nació el 28 de febrero de 1608" (JURADO, 2007, p. 34). Sin embargo, debió de dejar a Quiñones embarazada de su segundo hijo cuando viajó a Sevilla en 1607; de su estancia es posible suponer que marchó a las Indias, dejando tras de sí un negocio menos solvente que el que encontró:

La imprenta tiene una marcha ascendente, con trabajo, que se refleja documentalmente en los contratos de impresión y en las obligaciones, especialmente para la compra de papel. Se va corto de dinero, los pagos se aplazan y las deudas se acumulan (MOLL, 2005a, p. 482).

A pesar de que el responsable del taller era Juan de la Cuesta, la imprenta figuró a nombre de María Rodríguez de Ribalde hasta su muerte en 1627; tras la escapada indiana del impresor, la tarea pasó a ser realizada por Jerónimo de Salazar, como se ha detallado anteriormente, quien mantuvo la marca tipográfica "por Juan de la Cuesta" en ausencia de este, bajo mandato de la propietaria ${ }^{14}$. Es fácil suponer que María Rodríguez quisiera evitar el frecuente cambio de impresor de puertas afuera, lo que podría entenderse como inestabilidad en el negocio y la posible confusión respecto al taller de donde salían las ediciones. Pero además de la firma, también era esencial la marca del impresor, mediante la cual el comprador del volumen asociaría el ejemplar a unas prensas determinadas; en el caso de la imprenta fundada por Pedro Madrigal se adoptó la enseña del "halcón de cetrería, el león dormido en algunos casos, y la leyenda Post tenebras spero lucem (Job, XVII, 12)" (JURADO, 2007, p. 31); conforme recoge el investigador, otros editores habían utilizado esta enseña, pero quedará definitivamente asociada al estudio de Madrigal tras la impresión del Quijote en 1605.

\footnotetext{
${ }^{14}$ De cualquier modo, Juan de la Cuesta pasó a ser ampliamente conocido en el mundo editorial por imprimir por primera vez el Quijote en 1605, aunque el trabajo dista mucho de la cuidada corrección al presentar un gran volumen de erratas; el experto en la materia Francisco Rico (1998) estudia la "Historia del texto" con amplio detalle. También existe una publicación de corte divulgativo a cargo de Augusto Jurado (2007) sobre la figura de este impresor madrileño.
} 


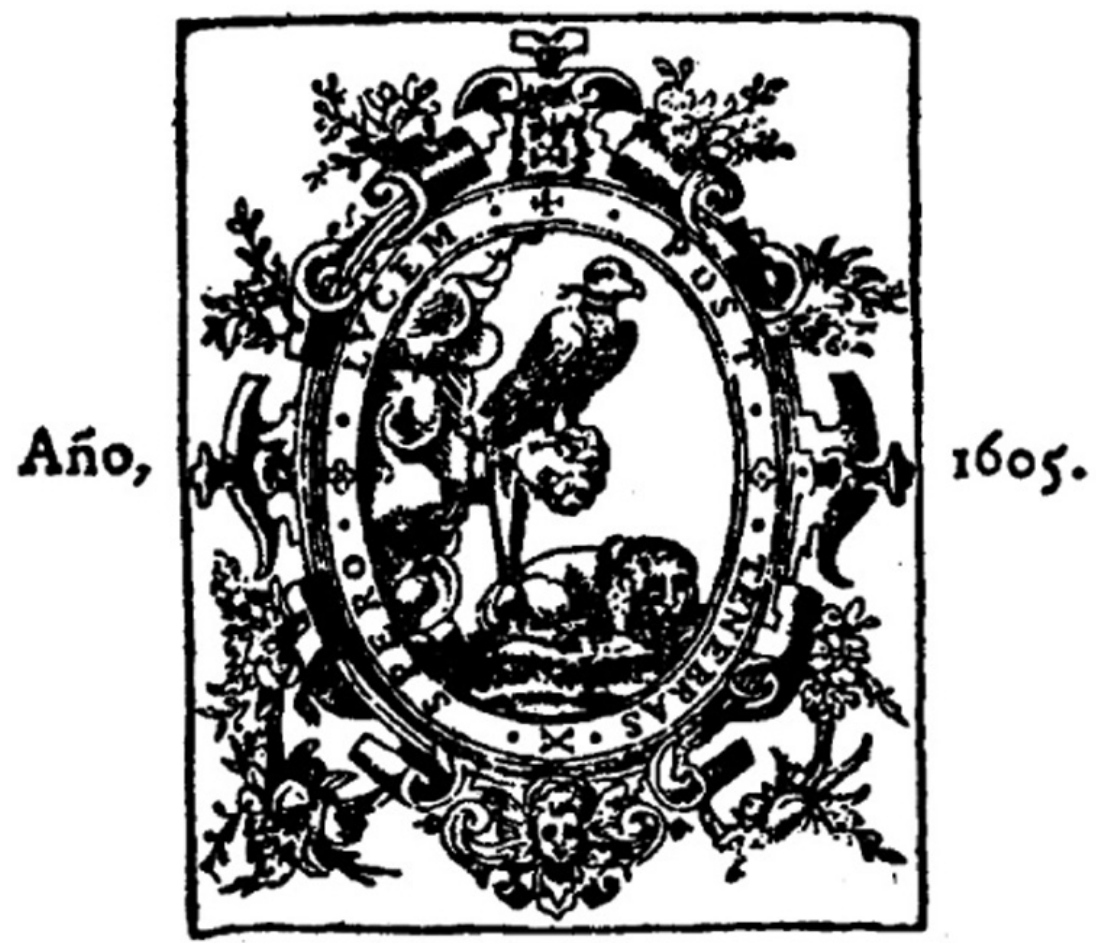

Imagen 1. Emblema en la ortada de El ingenio hidalgo Don Quijote de la Mancha. Compuesto por Miguel de Cervantes Saavedra, por Juan de la Cuesta a costa de Francisco de Robles en 1605, con el emblema de Pedro Madrigal. Biblioteca Hispánica Digital, BNE, signatura R/10282.

Por el contrario, tras la etapa iniciada por María de Quiñones, la impresora deshecha este símbolo y acompaña sus ediciones de ornamentos relacionados con la edición: retratos del autor, blasón de la casa del destinatario de la dedicatoria, etc. o bien de filigranas. Estos ejemplos ponen de manifiesto la maestría y delicadeza con que Quiñones acometía su oficio, hecho que la sitúa como digna heredera de Pedro Madrigal. 


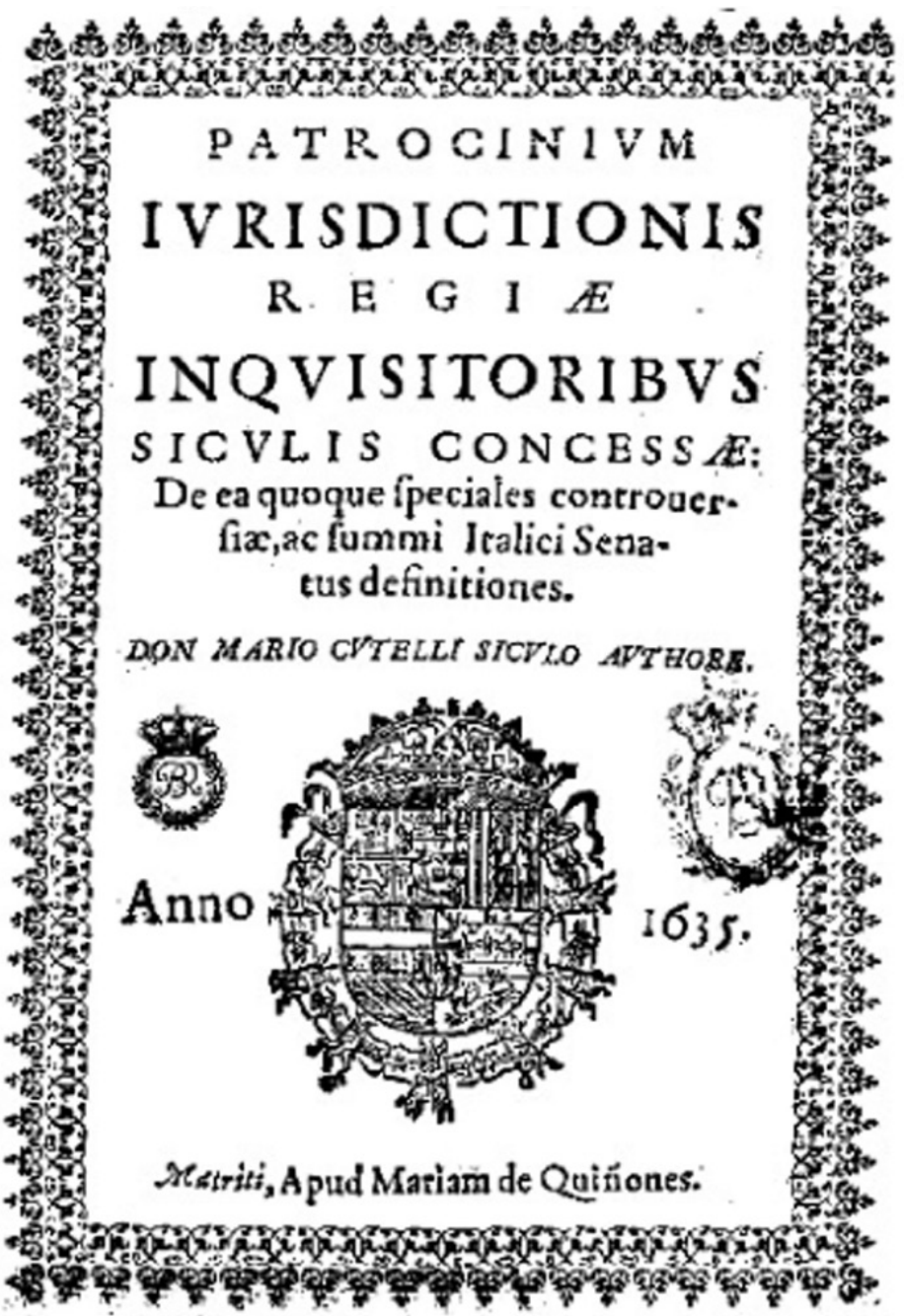

Imagen 2. Portada de Patrocinium pro regia iurisdictione inquisitoribus siculis concessa, de Mario Cutelli, impresa por Quiñones en 1633. Se aprecian ejemplos de filigranas. Biblioteca Hispánica Digital, BNE, signatura 7/15095. 


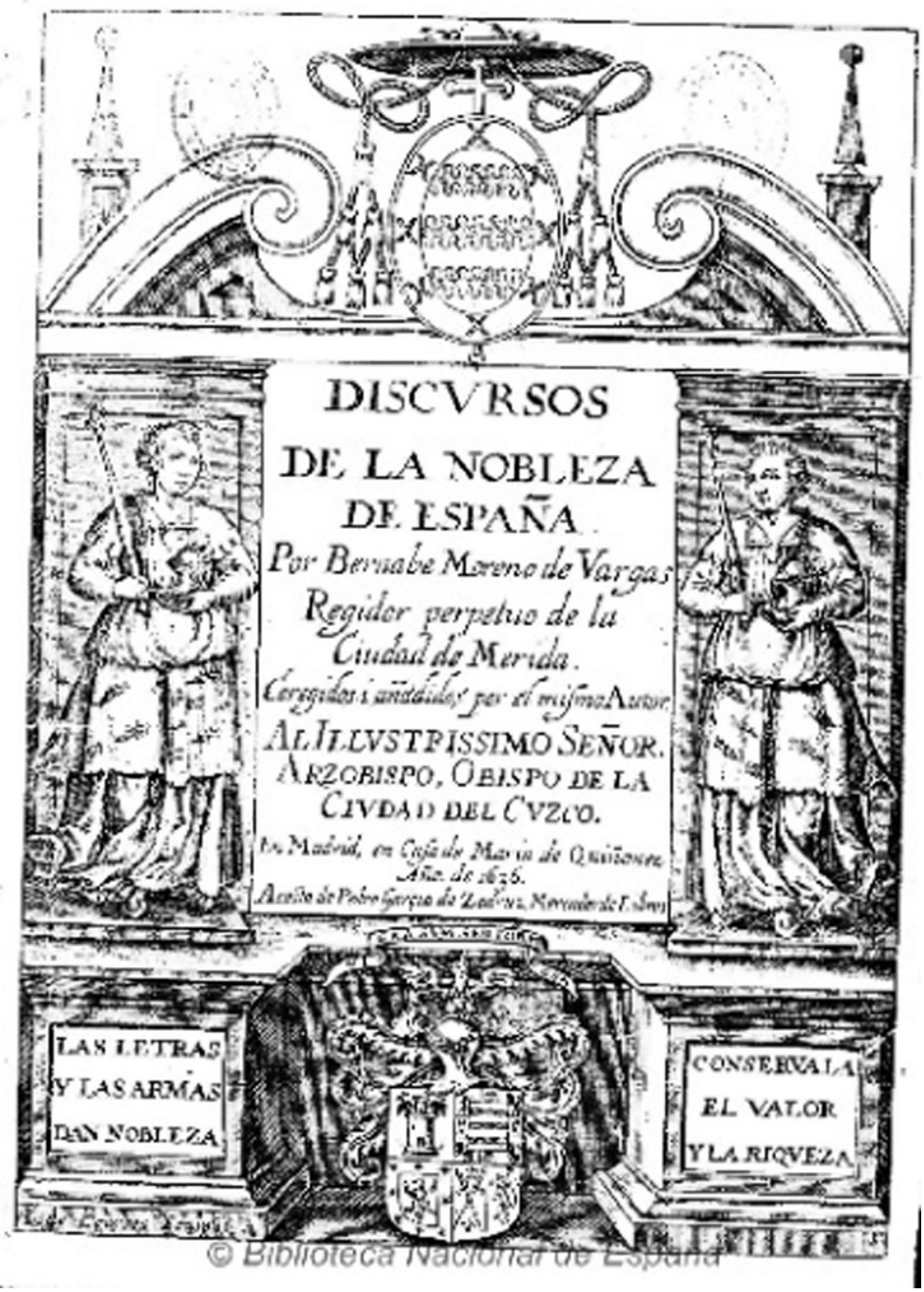

Imagen 3. Portada de Discursos de la nobleza de España, de Bernabé Moreno de Vargas, impresa por Quiñones a costa de Pedro García de Zodruz en 1636. Grabado firmado por I. de Courbes, con el que la editora realizará otros trabajos, como veremos en el caso de las obras del conde de Villamediana. Biblioteca Hispánica Digital, BNE, signatura 7/40458 (existen otros tantos ejemplares). 


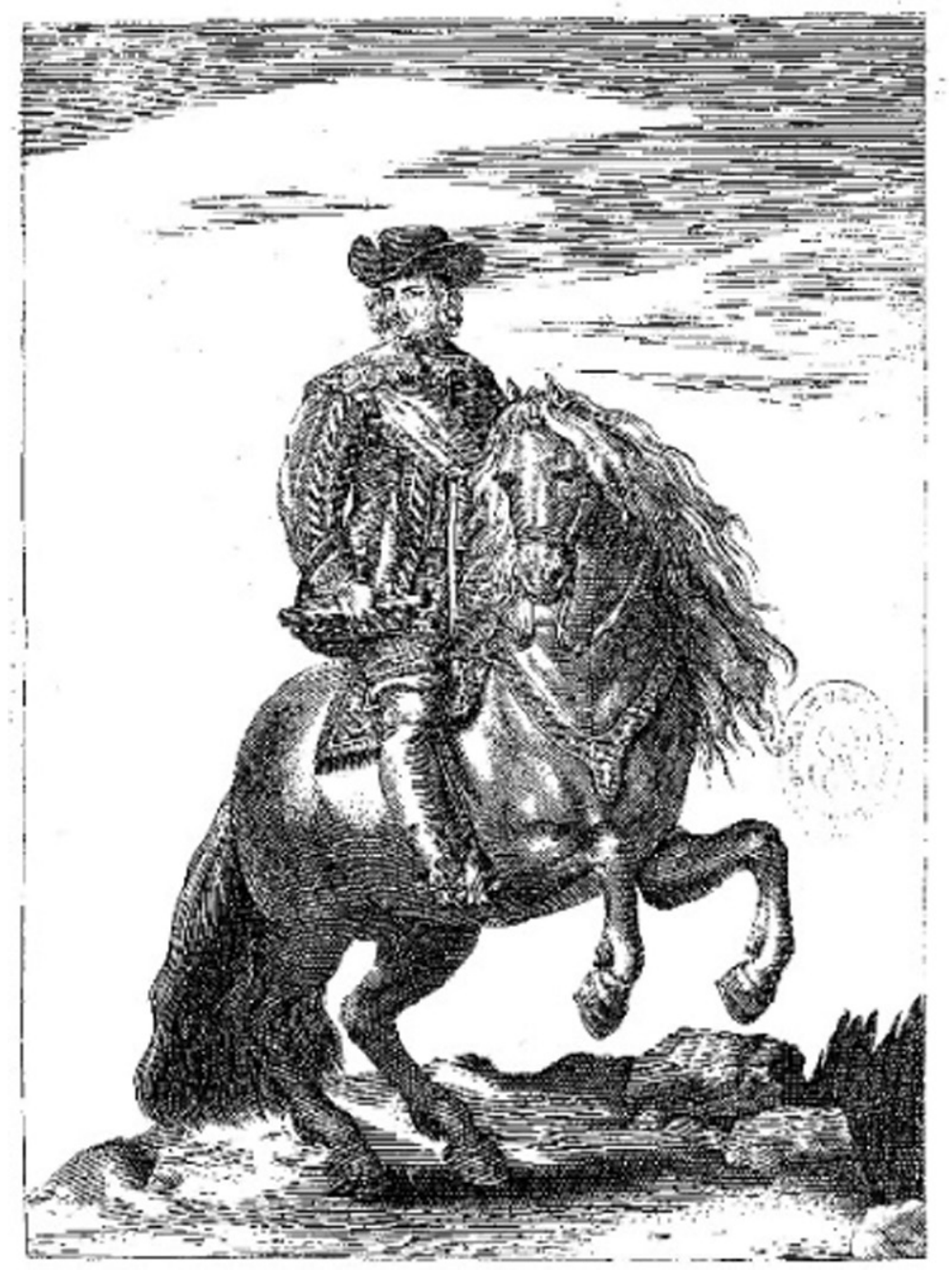

(c) Biblioteca Nacional de España

Imagen 4. Retrato del Cardenal Infante, al que se ofrecen las Relaciones del Cardenal Bentivollo, publicadas por María de Quiñones a costa de Pedro Coello en 1638. Biblioteca Hispánica Digital, BNE, signatura 2/38059. 


\section{Dos Familias en las Prensas: Madrigal y Quiñones}

No existen datos seguros acerca de los progenitores de Quiñones, más allá de la estrecha relación (posiblemente padre-hija) que le unía al documentado testigo de su enlace, Francisco de Quiñones. Nos despista la declaración incluida en el vuelto de la portada del Quijote impreso por Juan de la Cuesta en 1605: "El emblema es una de las varias marcas empleadas en la imprenta de Pedro Madrigal ( $†$ 1593), cuya hija estaba casada con el regente del taller Juan de la Cuesta" (Apud. JURADO, 2007, p. 12); es probable que a partir de esta afirmación se enuncien el resto de testimonios aportados a continuación (JURADO, 2007, p. 12-13). Sin embargo, el diccionario de impresores de Delgado expone: "El nombre de María de Quiñones aparece por primera vez relacionado con la imprenta como esposa de Pedro Madrigal, hijo del impresor del mismo nombre" (DELGADO, 1996, vol. 2, p. 566). Una hipótesis probable pero imposible de confirmar es que en realidad el segundo Pedro Madrigal fuera sobrino del fundador de la imprenta, hijo de un hermano suyo, de modo que María Rodríguez si fuera su tía; por otro lado, María de Quiñones podría ser hija de María Rodríguez y su anterior esposo Francisco de Quiñones. Así parece plausible que el primer Pedro Madrigal la llamase hija, al ser la descendiente de su actual cónyuge; quizá Madrigal no tuvo familia y propició el desposorio de la hija de su actual compañera con su sobrino. Si bien es cierto que no existe documento alguno que confirme esta suposición, tampoco las noticias disponibles la refutan.

Por tanto, las fechas aproximadas en que los diversos responsables del taller fundado por Pedro Madrigal ejercieron su labor resultarían las siguientes: 


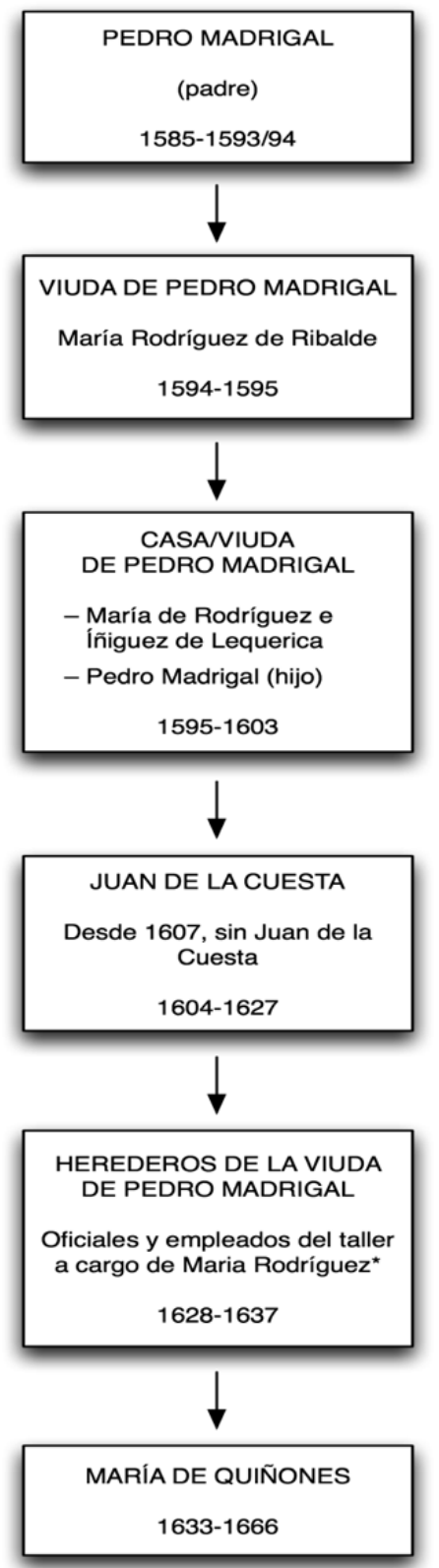

* No consta si durante este periodo la imprenta estuvo a cargo de los empleados del taller o del hijo de María de Quiñones con Juan de la Cuesta, aunque es más probable la primera opción, al no existir ningún registro de la actividad del descendiente de estos. Es posible añadir que no hay registro del nacimiento de vástagos durante el matrimonio entre Quiñones y Madrigal (hijo).

Imagen 5. Sucesivos herederos y encargados de la imprenta de Pedro Madrigal. 


\section{María de Quiñones heredera de la Imprenta de Pedro Madrigal}

Aunque la rúbrica “por María de Quiñones” empieza a mostrarse en las ediciones publicadas a partir de 1633, existe un breve espacio de tiempo durante el cual Quiñones no firma las obras salidas de su taller con su propio nombre, sino que recurre a "Herederos de la Viuda de Pedro Madrigal"; estas piezas se imprimieron en 1635 durante el primer año de colaboración editorial entre María de Quiñones y Pedro Coello:

1. Relación de la presa de la inexpugnable plaza, y fortaleza de Schinchen, en la provincia de Geldres, llave de Holanda: contiene el modo de conquistarla, que ha tenido el ejército del Serenísimo Señor Infante Cardenal. Madrid: por los Herederos de la viuda de Pedro de Madrigal: a costa de Pedro Coello mercader de libros, $1635^{15}$.

2. Declaración de su alteza el infante Cardenal tocante a la guerra contra la Corona de Francia: [Bruselas 24 de Junio de 1635] / Traducida de francés en español por don Martin Goblet... Madrid: Por los herederos de la viuda de Pedro de Madrigal: a costa de Pedro Coello mercader de libros, 1635.

3. Declaración de su alteza el Serenísimo Infante Cardenal tocante a la guerra contra la Corona de Francia: Bruselas a veinte de Junio año de mil y seiscientos y treinta y cinco / traducida de Francés en Español por don Martin Goblet... Madrid: por los herederos de la viuda de Pedro de Madrigal: Pedro Coello?, 1635.

4. Respuesta de un vasallo de su Majestad, de los Estados de Flandes, a los manifiestos del Rey de Francia / traducida de francés por don Martin Goblet... Madrid: por los herederos de la viuda de Pedro de Madrigal: a costa de Pedro Coello, 1635.

Todos ellos son escritos de tema bélico sobre los conflictos con Francia y Flandes en los que se encuentra inmersa la península en la década de 1630; quizá, la ausencia de la firma de Quiñones en detrimento de aquella referida a la imprenta fundada por Pedro Madrigal pueda explicarse por una razón de autoridad: la nueva propietaria del taller querría insertar sus trabajos en la estela de su fundador, aportando

\footnotetext{
${ }^{15}$ Como recoge López Poza en su artículo sobre relaciones de sucesos en torno al Cardenal Infante, esta relación sobre la conquista de Esquenque también se publicó en Barcelona por Pedro Lacavallería en 1635 (LÓPEZ POZA, 2015, p. 149).
} 
prácticamente de inmediato una gozosa reputación a los impresos en cuanto a calidad y maestría en el oficio.

En este momento da comienzo la fructífera relación editorial entre María de Quiñones y el librero Pedro Coello: España se encuentra en grave conflicto con los Países Bajos ${ }^{16} \mathrm{y}$ acaba de iniciar la guerra en Francia ${ }^{17}$, por lo que suponemos que toda la información (noticias, declaraciones, relaciones de sucesos, etc.) que de allí provenía fuera ampliamente leída en la península. Según han estudiado López Poza (2015) y Usunáriz Garayoa (2014), el medio escrito en este momento servía a la configuración de la propaganda a favor de la dinastía austriaca, en este caso el Cardenal Infante Fernando de Austria ${ }^{18}$. A pesar de la prescripción dada por Felipe IV en 1627 para controlar este tipo de publicaciones (lo que solo supuso que se hiciera caso omiso a los fracasos y derrotas, mientras que sí se difundían los avances), las relaciones de sucesos se multiplicaban con un claro propósito:

En estas relaciones, se hacen evidentes las tareas, capacidad, talento y preparación de lo que consideraríamos hoy un gabinete de comunicación o de prensa para ensalzar la imagen del cardenal infante y lograr una popularidad que era tan vital en el momento y el tiempo en que le tocó lidiar. Lamentablemente, no sabemos quiénes guiaron esta estrategia, pero es evidente que iba muy bien encaminada (LÓPEZ POZA, 2015, p. 160).

Por tanto, teniendo en cuenta el momento histórico que se estaba viviendo en España respecto a los conflictos con otras potencias europeas y las relaciones internacionales, la edición y venta de este tipo

\footnotetext{
${ }^{16}$ Tenía lugar la llamada "Guerra de los Ochenta Años", en la que las tropas de Flandes luchaban por independizarse de España; en este momento concreto, el comandante a cargo era Federico Enrique de Orange-Nassau. La guerra culminó en 1648 con la firma de la Paz de Münster, por la que se reconoció la independencia de estas provincias.

${ }^{17}$ En 1635 estalla la guerra entre Francia y España (que finalizará en 1659 con la Paz de los Pirineos) tras la victoria en Nördlingen de las tropas españolas frente a los suecos; como respuesta, Francia, aliada de Suecia en la Guerra de los Ochenta Años, decide comenzar el combate con España. Pueda ampliarse la información sobre el panorama bélico en que se encontraba inmersa la península en este periodo en: (ISRAEL, 2014).

${ }^{18}$ Desde la perspectiva de la pintura, podemos recordar la obra "La rendición de Breda" (también conocida como "Las lanzas") compuesta por Velázquez entre 1634-1635, en la que recrea la entrega de las llaves de esta ciudad al comandante Spínola; también, desde el teatro encontramos una aportación esencial: El sitio de Bredá, de Calderón de la Barca, e incluida precisamente en la Primera parte de comedias que imprimieron Quiñones y Coello en 1636. Al igual que una buena parte de la producción escrita estaba al servicio de la propaganda bélica, también encontramos ejemplos en otras formas de arte según analiza Van Der Auwera (2006) de manera general, y Van Maarseveen (1998) en las representaciones pictóricas de pequeños objetos.
} 
de obras sería una oportunidad de negocio importante que ni Quiñones ni Coello dejaron escapar, sino que aprovecharon presumiblemente con una amplia suma de beneficios.

Otro hecho curioso sucede en la impresión de los romances del condestable de Castilla Álvaro de Luna, que fueron recopilados por Pedro Ortega e impresos en la casa de Quiñones en 1636, 1637 y 1638 las partes tercera, segunda y primera respectivamente. Mientras parece que a partir de 1635, a excepción de los títulos arriba indicados la viuda de Madrigal empieza a firmar con su propio nombre, encontramos otro ejemplo (en este caso más aislado y sin razón aparente) de retorno a la rúbrica precedente: la impresión de los romances de 1637 la certifican los Herederos de la Viuda de Pedro Madrigal. Además de esta colección, existe otra publicada en ese mismo año, impresa en el taller de Quiñones sin que de nuevo aparezca su nombre propio, se trata de Cinco romances famosos: El primero del Cosario Barbaroja; El segundo de Arnaute Mami; El tercero del Maestre de Calatrava; El cuarto y quinto del Almirante don Garcerán / recopilados por Juan de Escobar; lleva al cabo una letrilla muy curiosa compilados por Juan de Escobar (1637). A partir de este momento las obras estampadas en el taller de la viuda de Madrigal llevarán como pie de imprenta, la leyenda "por María de Quiñones".

\section{En Casa de María de Quiñones, a Costa de Pedro Coello: Impresión de Grandes Ingenios Áureos}

Para completar este estudio sobre la imprenta fundada por Pedro Madrigal y heredada por María de Quiñones, creo que resulta interesante abordar un breve análisis del corpus de obras allí editadas y que fueron compuestas por los más destacados ingenios del Siglo de Oro español ${ }^{19}$. Como consecuencia, he decidido centrarme en este período tan beneficioso para impresores y libreros como es la vuelta de las licencias para publicar comedias tras la prohibición que abarca desde 16251634; buena cuenta de las necesidades de los autores dieron editores y mercaderes de libros, según podremos constatar con el ejemplo de la asociación establecida entre María de Quiñones y Pedro Coello, quienes, en los años inmediatamente posteriores al levantamiento del veto,

\footnotetext{
${ }^{19}$ La lista de obras salidas de las prensas de la editora es demasiado extensa y considero que no aportaría gran valor al poderse consultar con facilidad en los catálogos de las principales bibliotecas, por ejemplo la BNE.
} 
publicaron partes de comedias firmadas por Tirso de Molina, Calderón de la Barca o Lope de Vega.

En realidad, la falta de licencias para imprimir comedias en la década comprendida entre 1625-1634 no se debe a un decreto de prohibición, sino a la orden de no conceder nuevos permisos, aquellos necesarios para comenzar el proceso editorial de un volumen; la Junta de Reformación creada por Felipe IV en 1621 consideró que estos textos literarios que copiosamente se distribuían por la península haciendo las delicias de los lectores no resultaban adecuadas para la educación de los jóvenes por el relajo en las costumbres y la moral que las situaciones allí recreadas exponían. Las actas de aquella sesión celebrada el 6 de marzo de 1625 lo recogen:

Y porque se ha reconocido el daño de imprimir libros de comedias, novelas ni otros deste género, por el que blandamente hacen a las costumbres de la juventud, se consulte a su Majestad ordene al Consejo que en ninguna manera se dé licencia para imprimirlos (MOLL, 1974, s/p.).

Si la impresión de comedias se detuvo durante este periodo, no ocurrió lo mismo en el caso de las novelas, que sí continuaron saliendo de las prensas, aunque en menor medida que en épocas anteriores (CAYUELA, 1993). En cualquier caso, sin que se expresara la causa subyacente, en 1635 el Consejo del Rey retoma la dispensación para imprimir comedias en el reino de Castilla.

Muchas de estas partes de comedias que esperaban la normalización de la situación editorial fueron impresas por María de Quiñones y financiadas por Pedro Coello. De nuevo, como hemos expresado con anterioridad en el caso de los escritos histórico-políticos en torno a las guerras con Flandes y Francia, estas dos figuras vislumbraron una prolífica oportunidad de negocio con el siguiente panorama editorial: escritores necesitados de ingresos y deseosos de publicar sus comedias junto a lectores ávidos de nuevos enredos. Como veremos a continuación, no desaprovecharon la coyuntura, lo que sin duda les serviría a ambos para impulsar sus respectivos comercios, saldar deudas, obtener ingresos y darse a conocer en el mundo libresco del XVII. No sería este mal comienzo para la impresora María de Quiñones, quien justamente en esos años se empezaba a hacer cargo de la empresa heredada de Pedro Madrigal y contaría aún con obligaciones económicas tras la perjudicial gestión de su segundo esposo, Juan de la Cuesta. Es más que probable que los empleados de su taller fueran los verdaderos encargados de las 
prensas, ya que ella era analfabeta (al igual que María Rodríguez de Ribalde), pero supervisaría los trabajos que allí se imprimían, con un cuidado y gusto por el oficio como se venía haciendo en aquel local desde los tiempos del primer Pedro Madrigal.

A continuación se expone un listado de las obras resultado de la asociación entre Quiñones y Coello, pertenecientes al ámbito de la literatura y firmadas por los grandes ingenios del Siglo de Oro español. Cada título se acompaña de una pequeña descripción en torno a los más destacados avatares editoriales y/o peculiaridades de cada uno de los volúmenes.

\section{JuAn DE TASSis Y PERALTA. CONDE DE VILlamedianA}

- Obras de don Juan de Tassis Conde de Villamediana... / recogidas por... Dionisio Hipólito de los Valles... En Madrid: por María Quiñones: a costa de Pedro Coello y Manuel López..., 1635 (Frontispicio calcográfico firmado: "I de Courbes F"; se trataría del grabador Jean de Courbes, con quien Quiñones había trabajado en 1629).

En este volumen publicado póstumamente se recogen la Comedia de la gloria de Niquea, una silva y cinco fábulas versificadas de inspiración grecolatina. La aprobación está firmada por Lope de Vega y la dedicatoria dirigida a don Enrique de Zúñiga y Ávila, conde de Berantevilla; el autor de la misma es el librero Pedro Coello, quien hace buen uso de la ocasión editorial de la página escrita para realizar un laudatorio retrato del noble alavés.

\section{FRANCISCO DE QUEVEDO}

- Epicteto y Phocilides en español con consonantes / Con el origen de los estoicos y su defensa contra Plutarco y la defensa de Epicuro contra la común opinión... En Madrid: por María de Quiñones: a costa de Pedro Coello mercader de libros, 1635.

En los preliminares contiene un retrato de Quevedo, en hábito de caballero de Santiago, también impreso por Quiñones y realizado por Juan de Noort ese mismo año: el marco de la imagen principal está constituido por flores con tallo, y bajo la imagen del poeta se encuentra la siguiente inscripción: OVIDIO. Deme mihi studium, vitae quoque crimina demes (cita extraída del segundo libro de Las tristes). En la parte inferior del grabado se encuentran un león y un águila flanqueando una serpiente, junto a la lectura: Omnia Simul. La portada, también realizada por Noort, 
nos muestra en los cuatro extremos los retratos de Epicteto (a la derecha, arriba y abajo) y Focílides (a la izquierda, arriba y abajo); en el centro la figura de Epicteto más desarrollada con una luz en la mano (para alumbrar las tinieblas mediante el conocimiento) y un cartel que indica el título de la primera obra del volumen: Epicteto español en verso con consonantes del original más bien corregido. Se encuentra acompañado de tres figuras: una parece ser Cristo y los otros dos soldados.

Este libro recoge en realidad tres obras diferentes: Epicteto $y$ Phocilides, Origen de los estoicos y Defensa de Epicuro contra la opinión común; la estudiosa Otaola González traza un buen panorama del origen y creación de estas obras (que explica en varios folios el propio autor en el prólogo):

(...) consiste en la traducción del Manual del filósofo griego, compuesto en 1633, según Michèle Gendreau, y la del Carmen admonitorum del Pseudo-Phocylides, que remonta a 1609. La traducción de Epicteto está basada en la Manuductio ad stoicam philosohiam de Justo Lipsio y en la traducción de Sánchez de las Brozas a la que sigue de cerca. (OTAOLA GONZÁLEZ, 2004, p. 14-15)

La Defensa de Epicuro sería un estudio del filósofo, trazando una figura cercana a los preceptos del cristianismo; este libro, junto con el Origen de los estoicos podría ser datado en 1612, aunque el texto de la Defensa no sería definitivo hasta 1630.

Por último, es necesario añadir que el librero que costeó este tomo, Pedro Coello, fue el gran responsable de compilar la voluminosa obra literaria quevediana, según estudia con detalle Moll (1998).

\section{TIRSO DE MOLINA}

- Cuarta Parte de las comedias. En Madrid: por María Quiñones: a costa de Pedro Coello y Manuel López..., 1635.

Esta Cuarta Parte tirsiana viene avalada por la labor editorial de Francisco Lucas de Ávila, sobrino del dramaturgo mercedario, al igual que las partes Segunda ${ }^{20}$, Tercera ${ }^{21}$ y Quinta $^{22}$, que como puede

\footnotetext{
${ }^{20}$ En Madrid: en la Imprenta del Reino: a costa de la Hermandad de los Mercaderes de Libros de esta Corte, 1635.

${ }^{21}$ Impreso en Tortosa: en la Imprenta de Francisco Martorell: a costa de Pedro Escuer..., 1634; presenta una fecha anterior al permiso de imprimir nuevamente comedias en Castilla, porque el volumen apareció en Cataluña.

${ }^{22}$ En Madrid: en la Imprenta Real: a costa de Gabriel de León, 1636.
} 
comprobarse, se publican sin apenas espacio de tiempo entre 1634-1636; la razón de esta abundancia es la prohibición de imprimir comedias y novelas dictada por la Junta de Reformación de Castilla en 1625, que se prolongó durante una década. La justificación que se aduce es la laxitud de costumbres que propicia:

Y porque se ha reconocido el daño de imprimir libros de comedias, novelas ni otros de este género, por el que blandamente hacen a las costumbres de la juventud, se consulte a su Majestad ordene al Consejo que en ninguna manera se dé licencia para imprimirlos (MOLL, 1974, s/p.).

Es sabido que los autores utilizaban sus prólogos para ensalzar la fama y virtudes de sus benefactores, pero examinando los paratextos de las impresiones podemos encontrar otros datos de relevante interés acerca de los procesos editoriales; los más valiosos para el propósito de este trabajo serían los relativos a otros libreros o impresores contemporáneos, información que nos proporciona Tirso de Molina en la apertura de esta Cuarta Parte. Imaginamos a un autor molesto e irritado por la prohibición de la Junta de Reformación, que no solo impedía la publicación de obras verdaderas por parte de los dramaturgos, sino que favorecía la proliferación de textos falsamente atribuidos, espurios, etc. El mercedario escribe estas palabras puestas en boca de la Cuarta Parte de comedias:

(...) búscame (cuando haya salido de la cuna mi hermano, el quinto de este nombre) hallarasme en la tienda de Gabriel de León, mercader de estas sazones, y nos daremos un buen rato a costa de los abusos en especie, sin riesgo de los individuos (TIRSO DE MOLINA, 1635, s/p.).

Se hace alusión al señalado mercader de libros, quien imprimió la Quinta Parte tirsiana en 1636: según estudia Moll, en 1651 tiene lugar una acusación criminal por parte de impresores hacia libreros, entre los que se encuentran Gabriel de León. La motivación de tal proceso era el enriquecimiento de estos mercaderes durante la prohibición de imprimir comedias en Castilla: frente a esta situación llevan las obras a imprentas francesas, lo que genera un trasvase económico con este reino enemigo, a la vez que se perjudica a las imprentas madrileñas. Los perjuicios para todos aquellas partes implicadas en la producción de libros es clara: 
Por otra parte los libros importados no pagan impuestos, mientras que los impresos en los reinos de Castilla pagan por el papel, con lo que también sufre menoscabo la hacienda real, además del perjuicio ocasionado a los molinos papeleros. Los impresores fijan el inicio del hecho denunciado más de dieciséis años antes (MOLL, 2013, s/p.) $)^{23}$.

Es notable la implicación del dramaturgo en el proceso editorial al utilizar el prólogo para denunciar la situación de enriquecimiento y fraude libresco por parte de los propios mercaderes. E1 beneficio obtenido debía ser cuantioso porque, según observa Agulló y Cobo, disfrutó de lujos varios: coches, casas, criados, cocheros, etc., además de ser recaudador del impuesto del papel y prestamista (AGULLÓ Y COBO, 1992, p. 9); es fácil comprender la indignación de Tirso de Molina al conocer el lucro que su obra y la de sus compañeros dramaturgos ofrecía a estos mercaderes mientras él luchaba por ver sus comedias publicadas y justamente atribuidas.

\section{Pedro CALDERÓN DE LA BARCA}

- Primera Parte de las Comedias de don Pedro Calderón de la Barca I recogidas por don Joseph Calderón de la Barca, su hermano... En Madrid: por María de Quiñones: a costa de Pedro Coello y de Manuel López..., 1636.

- Segunda Parte de las Comedias, de don Pedro Calderón de la Barca I recogidas por don Joseph Calderón de la Barca, su hermano... En Madrid: por María de Quiñones: a costa de Pedro Coello, 1637.

Estos dos volúmenes fueron llevados al taller por el hermano del dramaturgo para poner fin a la proliferación de textos impresos adjudicados a Calderón, lo que como consecuencia configuraba un extenso y farragoso panorama editorial ${ }^{24}$. El propio José Calderón de la Barca enuncia los motivos subyacentes a la impresión en su dedicatoria a don Bernardino Fernández de Velasco y Tobar, condestable de Castilla:

\footnotetext{
${ }^{23}$ Precisamente esa fecha nos remite a 1635, año de publicación de la Cuarta Parte.

${ }^{24}$ Para más detalles, (PINILLOS, 1997, p. 48); se estudian aquí de manera breve las cuestiones más sobresalientes sobre los avatares editoriales de las piezas calderonianas desde el XVII hasta nuestros días.
} 
(...) no ha sido tanto el gusto de verlas impresas como el pesar de haber visto impresas algunas dellas antes de ahora, por hallarlas todas erradas, mal corregidas y muchas que no son suyas en su nombre, y otras que lo son en el ajeno (...) (CALDERÓN DE LA BARCA, 1636, s/p.).

Poseen el mismo tipo de letra y también, a propósito de la Segunda Parte: "Es de suponer, pues, que, como se ha concluido para la Primera Parte [...] el propio don Pedro participase de alguna manera en la recogida de los textos manuscritos o impresos que le sirvieron de base" (RUANO DE LA HAZA, 1998, p. 36). Afirmación que confirma Paterson respecto de la Primera parte, a la vez que añade:

Retrospectivamente, el título hace tabla rasa de cualquier otra publicación no autorizada. La promesa de futuras partes que es implícita en el título se cumplió efectivamente hasta que la piratería intervino simulando una Quinta Parte que cortó el hilo que luego iba a recoger Juan de Vera Tassis. No vacilo en concluir que la intencionalidad a que me refiero es autorial; el mismo Calderón inicia y da noticia del trasvase de su teatro al libro (PATERSON, 2001, s/p.).

A propósito de la Segunda parte existe un completo análisis de Fernández Mosquera, (2008) ${ }^{25}$; afirma el investigador, siguiendo las tesis propuestas por Heaton y continuadas, por ejemplo, por Caamaño Rojo (2001, p. 48-51) en su edición crítica de El mayor monstruo del mundo, que existen dos publicaciones de la Segunda Parte con fecha de 1637, una a nombre de María de Quiñones únicamente, y otra acompañada de la leyenda "a costa de Pedro Coello". A pesar de las múltiples erratas de este último texto (denominado QC, Quiñones y Coello), se ha fijado como la impresión príncipe para los subsiguientes estudios textuales de las comedias allí contenidas, por la cercanía de sus versos al original calderoniano. Por el contrario, la impresión sin referencia al librero Coello parece ser una contrahecha publicada en 1670 aunque indique fecha anterior, y de ninguna manera publicada por Quiñones quien dejó de trabajar en su taller en 1666.

\footnotetext{
${ }^{25}$ También Rodríguez-Gallego (2010) estudia este volumen rastreando las incursiones calderonianas en el mismo.
} 


\section{LOPE DE VEGA Y CARPIO ${ }^{26}$}

- Parte veinte y tres de las comedias de Lope Félix de Vega Carpio ${ }^{27}$. En Madrid: por María de Quiñones: a costa de Pedro Coello..., 1638. Errores de foliación: pasa de h. 125 a la 128 y de la 130 a la 141.

De este mismo tomo, y como modo de rentabilizar el texto obteniendo mayor beneficio económico, se publican desglosadas las siguientes comedias: Contra valor no hay desdicha, La envidia de la nobleza y El saber por no saber y vida de S. Julián, de Alcalá de Henares.

Esta Parte XXIII se publica de manera póstuma, al igual que las partes XXI y XXII ${ }^{28}$ dispuestas por José Ortiz de Villena; esta edición de 1638 está dedicada a don Gutierre Domingo de Terán y Castañeda, señor de la Casa de Terán del Valle Iguña Montañas de Burgos, y acompañada de una preciosista reproducción del escudo de armas de esta familia ${ }^{29}$. El mercader Pedro Coello solicita al erudito portugués Manuel de Faria e Sousa la escritura del prólogo, quien explicita la relación entre ellos:

Hallándose Pedro Coello Mercader de libros en esta Corte, al fin de la impresión de esta Parte XXIII de las comedias del siempre admirable Lope, dejó a mi elección la dedicatoria de ellas, fiando de la amistad que en mi conoce, $\mathrm{y}$ del conocimiento que tengo de personas capaces, que le emplearía bien (VEGA Y CARPIO, 1638, s/p.)

\footnotetext{
${ }^{26}$ De este autor, María de Quiñones también publicó Alabanzas al glorioso patriarca S. José, esposo de la madre de Dios; con tres Romances: el primero al Nacimiento del Niño Jesús, El segundo de Gaiferos, vuelto a lo divino, El tercero de Cristo buscando al alma. En Madrid: por María de Quiñones: véndese en casa de Juan de Valdés enfrente de Santo Tomas, 1656. Esta obrita se debió imprimir y vender suelta, se trata de un pliego; no ofrece información del editor y carece de dedicatoria. Según confirma Carreño, no se trata esta de la edición príncipe, sino de la última de las reediciones impresas: "De las Alabanzas al glorioso patriarca san José, esposo de la madre de Dios; con tres Romances [...], Madrid, 1656, existen cuatro ediciones diferentes en el siglo XVII; sale una en Málaga, en 1616 [...] otra en Sevilla, en 1628, que reproduce en facsímil el librero Julián Barbazán; otra en Madrid, 1656, uno de los ejemplares en la Biblioteca Nacional" (CARREÑO, 2005, pp. XXXVI-XXXVII). Según atestigua Ruiz Pérez (2013, p. 188), la edición malagueña de este pliego (al que califica de hagiográfico) en 1616 fue impresa por Antonio René.

${ }^{27}$ No confundir esta publicación con el volumen espurio publicado en Valencia por Miguel Sorolla en 1629; para ampliar la información, consultar Hernández González (1992), donde se trata específicamente esta curiosidad editorial.

${ }^{28}$ La mayoría de estas Partes de comedias se encuentran revisadas en el texto de Jaime Moll, De la continuación de las partes de comedias...; el autor explica de modo cronológico cómo se fue sucediendo la publicación los volúmenes, dependientes de concesiones de licencias y privilegios.

${ }^{29}$ En 1629, cuando María de Quiñones aún firmaba como "Herederos de la Viuda de Pedro Madrigal", y costeadas por el grabador francés Jean de Courbes, salieron de sus prensas varios documentos gráficos relativos a escudos: casa de Mendoza y Rojas, casa de Cañete, casa de Alarcón y condes de Valverde, ciudad de Cuenca, etc., de modo que la impresora estaría familiarizada con esta expresión artística.
} 
Nuevamente comprobamos la estrecha relación entre autores y libreros en el Siglo de Oro español.

\section{FRANCISCO ROJAS ZORRILLA ${ }^{30}$}

- Primera parte de las comedias de don Francisco de Rojas Zorrilla. En Madrid: por María de Quiñones: a costa de Pedro Coello..., 1640.

\section{Conclusiones}

A lo largo de estas páginas, hemos comprobado el constante recorrido de la imprenta fundada por Pedro Madrigal, natural de Salamanca, en la madrileña calle de Atocha. Tras la desaparición del maestro impresor, le sucedieron en la tarea su viuda, María Rodríguez de Ribalde, junto con su segundo esposo, también perteneciente al gremio, Juan Íñiguez de Lequerica; asimismo, durante un periodo de tiempo no confirmado, puesto que no firma con su nombre propio en las obras que edita, allí trabajo un segundo Pedro Madrigal, quien contraería matrimonio con María de Quiñones. De nuevo, con el fallecimiento del cónyuge, la viuda busca un nuevo esposo impresor para poder continuar con el negocio; Quiñones se casa en 1602 con Juan de la Cuesta, responsable de la primera edición del Quijote, poco competente para los negocios, quien abandona a su mujer embarazada para emigrar a las Indias en 1607. María Rodríguez se pone de nuevo al mando del comercio hasta su muerte, y la sucederá María de Quiñones, de quien tenemos registro que empieza a rubricar con su propio nombre en 1633. Sin embargo, cuando publica escritos políticos durante 1635 a costa de Pedro Coello, vuelve a la firma anterior de "Viuda de Pedro Madrigal", en un intento de enlazar su trabajo con la reputada trayectoria de la imprenta que dirige.

En cualquier caso, a pesar del cambio de regentes (casi uno por década), las dos figuras más sobresalientes que sucedieron a Pedro Madrigal (padre), María Rodríguez de Ribalde y María de Quiñones respectivamente, se afanaron por dar continuidad a los trabajos realizados en su imprenta. Esta acción es posible al mantener el emblema de la casa Madrigal (halcón y león con inscripción del libro de $J o b$ ) y la mención a su fundador en la firma, así se hizo hasta la llegada de Juan de la Cuesta. El cambio de titular en las obras impresas fue decisión de María Rodríguez, quien decidió mantenerlo aunque durante dos décadas

${ }^{30}$ De las prensas de Quiñones también sale el volumen Autos sacramentales: con cuatro comedias nuevas y sus loas y entremeses: primera parte. En Madrid: a costa de Juan de Valdés..., 1655. 
el taller funcionara sin su maestro. Cuando Quiñones asume la dirección de la imprenta utiliza su nombre, a excepción de los casos reseñados, y comienza por tanto una nueva etapa en el negocio.

Resultó afortunada María de Quiñones al heredar una imprenta en funcionamiento, con máquinas y herramientas suficientes para el desempeño de una labor editorial competente y minuciosa, que complementó con un golpe de fortuna: editar los textos de esenciales autores auriseculares tras el estancamiento que supuso la prohibición de 1624. No sería arriesgado para Quiñones y el librero Pedro Coello el invertir tiempo y dinero en imprimir esas obras (en la mayor parte de casos firmadas por escritores ya reputados), que sin duda gozarían de la acogida inmediata por parte del público. Además de este golpe de suerte, que aprovecharon con destreza, también trabajaron juntos en los escritos de índole política alrededor de las guerras que enfrentaban a España con Flandes y Francia. Dos circunstancias de negocio que supieron aprovechar, tanto para el beneficio económico como para la reputación profesional de estos dos comerciantes que apenas acababan de iniciar su andadura.

Después de esta colaboración, tanto Quiñones como Coello seguirían en sus respectivos locales, pero en ninguno de los dos casos encontramos una asociación tan provechosa y duradera con otros libreros e impresores respectivamente como el suceso aquí mencionado. Como consecuencia, ambos nombres pueden ser inscritos con letra mayúscula en las historias de la imprenta y los impresos en España; y yendo aún más allá sobresale la figura de María de Quiñones al mando de un reputado taller, exitosa visionaria en el negocio editorial del Siglo de Oro español.

\section{Referencias}

AGULLÓ Y COBO, Mercedes. La imprenta y el comercio de libros en Madrid (siglos XVI-XVIII). Tesis doctoral, Universidad Complutense de Madrid, 1992.

CAAMAÑO ROJO, María J. El mayor monstruo del mundo de Calderón de la Barca. Estudio textual. Santiago de Compostela: Universidade de Santiago de Compostela, 2001.

CALDERÓN DE LA BARCA, Pedro. Primera Parte de las comedias de don Pedro Calderón de la Barca / recogidas por don Joseph Calderón de la Barca, su hermano... En Madrid: por María de Quiñones: a costa de Pedro Coello y de Manuel López..., 1636.

. Segunda Parte de las Comedias, de don Pedro Calderón de la Barca / recogidas por don Joseph Calderón de la Barca, su hermano... En Madrid: por María de Quiñones: a costa de Pedro Coello, 1637.

CARREÑO, Antonio (Ed.). Lope de Vega. Poesía VI. Huerto deshecho. Égloga a Claudio. La Vega del Parnaso. Otros versos. Madrid: Biblioteca Castro, 2005. 
CAYUELA, Anne. La prosa de ficción entre 1625-1634. Balance de diez años sin licencias para imprimir novelas en los reinos de Castilla. Mélanges de la Casa de Velázquez, v. 29, n. 2, p. 51-76, 1993. http://dx.doi.org/10.3406/casa.1993.2649

CORTÉS CORRAL, Mónica; MÉNDEZ VIAR, Victoria. Impresoras madrileñas en el Siglo de Oro: Juana Martínez de Angulo. Anexos de Signo, v. 4, p. 185-211, 2001.

DADSON, Trevor J. La librería de Miguel Martínez (1629), librero y editor del primer tercio del siglo XVII. Bulletin Hispanique, v. 99, n. 1, p. 41-71, 1997. http://dx.doi.org/10.3406/hispa.1997.4926

DELGADO CASADO, Juan. Diccionario de impresores españoles: siglos XV-XVII. Madrid: Arco/Libros, 1996. 2 v.

ESCOBAR, Juan de. Cinco romances famosos: El primero del Cosario Barbaroja; El segundo de Arnaute Mami; El tercero del Maestre de Calatrava; El cuarto y quinto del Almirante don Garcerán/recopilados por Juan de Escobar; lleva al cabo una letrilla muy curiosa. Impreso en Madrid: por los herederos de la viuda de Pedro Madrigal, 1637.

FERNÁNDEZ MOSQUERA, Santiago. Los textos de la Segunda parte de Calderón. Anuario Calderoniano, v. 1, p. 127-150, 2008.

FERNÁNDEZ VEGA, María del Mar. Jerónima de Gales. Una impresora valenciana del siglo XVI. In: CÁTEDRA GARCÍA, Pedro Manuel; PÁIZ HERNÁNDEZ, María Isabel; LÓPEZ-VIDRIERO ABELLO, María Luisa (Coords.). En La memoria de los libros: estudios sobre la historia del escrito y de la lectura en Europa y América. Salamanca: Instituto de Historia del libro y de la lectura, 2004. v. 1. p. 405-34.

GRIFFIN, Clive. Los Cromberger. La historia de una imprenta del siglo XVI en Sevilla y en Méjico. Madrid: Ediciones de Cultura Hispánica, 1991.

. Brígida Maldonado 'ymprimidora' sevillana, viuda de Juan Cromberger. Archivo Hispalense, v. LXXVI, n. 23, p. 83-117, 1993.

HERNÁNDEZ GONZÁLEZ, Erasmo. Una desconocida parte de comedias de Lope (Parte XXIII, Valencia, 1619). Criticón, v. 56, p. 179-186, 1992.

ÍÑIGUEZ DE LEQUERICA, Juan (Ed.). Sermones funerales en las honras del Rey nuestro Señor don Felipe II, con las que se predicó en las de la sereníssima Infanta D. Catalina Duquesa de Saboya. En Madrid: por los herederos de Juan Íñiguez de Lequerica, a costa del Licenciado Várez de Castro, 1701.

ISRAEL, Jonathan I. El ejército de Flandes entre dos frentes (1635-1637). Desperta Ferro: Historia moderna, 2014. v. 9. p. 24-31.

JURADO, Augusto. Juan de la Cuesta, impresor de El Quijote, por encargo del librero Francisco de Robles, y breves noticias de ambos y del autor de la obra, Miguel de Cervantes. Madrid: C\&G, Comunicación Gráfica, 2007.

LÓPEZ POZA, Sagrario. Relaciones impresas (años 1632-1642) sobre el Cardenal Infante don Fernando de Austria. In: GARCÍA LÓPEZ, Jorge; BOADAS, Sònia (Eds.). Las relaciones de sucesos en los cambios politicos y sociales de la Europa Moderna. Studia Aurea Monográfica, 2015. v. 6. p. 141-161,

MOLL, Jaime. Diez años sin licencias para imprimir comedias y novelas en los reinos de Castilla: 1625-1634. Alicante: Biblioteca Virtual Miguel de Cervantes, 1974. Disponible en Cervantes Virtual: < http://www.cervantesvirtual.com/obra-visor/diez-aossin-licencias-para-imprimir-comedias-y-novelas-en-los-reinos-de-castilla-16251634-0/ html/0213242e-82b2-11df-acc7-002185ce6064_3.html>. Acceso en: 16 mar. 2016. 
. El proceso de formación de las "Obras completas" de Quevedo. Alicante: Biblioteca Virtual Miguel de Cervantes, 1998. Disponible en Cervantes Virtual: $<$ http://www.cervantesvirtual.com/obra-visor/el-proceso-de-formacion-de-las-obrascompletas-de-quevedo/html/6f757473-b976-44d3-927d-017d3d411ec3_3.html>. Acceso en: 16 mar. 2016.

. Juan de la Cuesta. In: Boletín de la Real Academia Española, v. 85, n. 291-292, p. 475-484, 2005a.

. El taller donde se imprimió el Quijote. Alicante: Biblioteca Virtual Miguel de Cervantes 2005b. Disponible en Cervantes Virtual: <http://www.cervantesvirtual. $\mathrm{com} /$ portales/universidad_iberoamericana/obra-visor-din/el-taller-donde-se-imprimioel-quijote/html/6639e1c8-ee5f-4d4b-bb36-1c25815f0b06_4.html>. Acceso en: 30 mar. 2016.

. De Impresores y Libreros: un pleito de 1651. Alicante: Biblioteca Virtual Miguel de Cervantes, 2013. Disponible en Cervantes Virtual: <http://www.cervantesvirtual. com/obra-visor-din/de-impresores-y-libreros--un-pleito-de-1651/html/ >. Acceso en: 01 oct. 2016.

ORTEGA, Pedro (Ed.). Tercera parte de los romances de don Álvaro de Luna. Madrid: María de Quiñones, 1636.

. (Ed.). Segunda parte de los romances de don Álvaro de Luna. Madrid: Herederos de la viuda de Pedro de Madrigal, 1637.

. (Ed.). Primera parte de los romances de don Álvaro de Luna; corregidos por el Padre Juan Besgue de la Compañía de Jesús. Madrid: María de Quiñones, 1638.

OTAOLA GONZÁLEZ, Paloma. Coordenadas filosóficas del pensamiento de Quevedo. Obras filosóficas y satírico-morales. Alicante: Club Universitario, 2004.

PATERSON, Alan K. G. La socialización de los textos de Calderón: El legado de don Juan de Vera Tassis y don Pedro de Pando y Mier. New York: Peter Lang, 2001. Disponible en Cervantes Virtual: <http://www.cervantesvirtual.com/obra-visor/lasocializacin-de-los-textos-de-caldern-el-legado-de-don-juan-de-vera-tassis-y-donpedro-de-pando-y-mier-0/html/021de616-82b2-11df-acc7-002185ce6064_2.html>. Acceso en: 21 mar. 2016.

PEDRAZA GARCÍA, Manuel José. Juana Millán, señora de la imprenta: Aportación al conocimiento de una imprenta dirigida por una mujer en la primera mitad del siglo XVI. In: Bulletin Hispanique, v. 11, n. 1, p. 51-73, 2009a.

. Las mujeres en la imprenta hispana durante los siglos XV y XVI. Homenaje a Isabel de Torres Ramírez: estudios de documentación dedicados a su memoria. Granada: Universidad de Granada, 2009. p. 587-606.

PÉREZ PASTOR, Cristóbal. Bibliografia madrileña ó descripción de las obras impresas en Madrid (siglo XVI). Madrid: Tipografía de los Huérfanos, 1891.

PINILlOS, Ma Carmen. Bibliografía calderoniana. Fortuna editorial de Calderón. In: Anthropos, v. extra, n. 1, p. 48-51, 1997.

RICO, Francisco. Historia del texto. In: Don Quijote de la Mancha. Ed. Francisco Rico, 1998. Disponible en Cervantes Virtual: <http://cvc.cervantes.es/literatura/clasicos/ quijote/introduccion/prologo/rico.htm>. Acceso en: 21 mar. 2016.

RODRÍGUEZ-GALLEGO, Fernando. Las huellas textuales de Calderón en su Segunda parte. In: Criticón, v. 108, p. 99-114, 2010. 
ROJAS ZORRILLA, Francisco de. Primera parte de las comedias de don Francisco de Rojas Zorrilla. En Madrid: por María de Quiñones: a costa de Pedro Coello..., 1640.

. Autos sacramentales: con cuatro comedias nuevas y sus loas y entremeses: primera parte. En Madrid: por María de Quiñones: a costa de Juan de Valdés..., 1655.

RUANO DE LA HAZA, José Ma․ Las dos versiones de El mayor monstruo del mundo de Calderón. In: Criticón, v. 72, p. 35-47, 1998.

RUIZ PÉREZ, Pedro. Los pliegos de Lope. In: E-Humanista, v. 24, p. 165-193, 2013.

RUMEAU, Aristide. Isabel de Basilea: mujer impresora. In: Bulletin Hispanique, v. 73, p. 231-247, 1971. http://dx.doi.org/10.3406/hispa.1971.4046

SÁNCHEZ COBOS, Ma Dolores. Mariana de Montoya, una mujer impresora en Baeza de comienzos del XVII. In: CÁTEDRA GARCÍA, Pedro Manuel, PÁIZ HERNÁNDEZ, María Isabel, LÓPEZ-VIDRIERO ABELLO, María Luisa (Coords.). La memoria de los libros: estudios sobre la historia del escrito y de la lectura en Europa y América. Salamanca: Instituto de Historia del Libro y de la Lectura, 2004. v. 1. p. 365-379.

TIRSO DE MOLINA. Cuarta Parte de las comedias. En Madrid: por María Quiñones: a costa de Pedro Coello y Manuel López..., 1635.

USUNÁRIZ GARAYOA, Jesús María. El inicio de la Guerra de los Treinta Años en la publicística española: la Defenestración de Praga y la Batalla de la Montaña Blanca. In: Perinola, Revista de investigación quevediana. v. 18, p. 181-213, 2014.

VAN DER AUWERA, Johan. La guerra y su representación en el arte durante el Antiguo Régimen. El caso de la guerra de los Ochenta Años (1568-1618-1648). In: GARCÍA GARCÍA, Bernardo José (Coord.). La imagen de la guerra en el arte de los antiguos Países Bajos. Madrid: Fundación Carlos de Amberes, 2006. p. 29-62.

VAN MAARSEVEEN, Michel P. La Guerra de los ochenta años representada en grabados, medallas y azulejos. In: GEENS, Catherine (Ed.). El final de la Guerra de Flandes (1621-1648): 350 aniversario de la paz de Münster. Madrid: Fundación Carlos de Amberes, 1998. p. 61-74.

VÁZQUEZ MADRUGA, Ma Jesús. Juana Martínez de Angulo: una impresora de Alcalá de Henares a finales del s. XVI. In: Cuadernos para investigación de la literatura hispánica, v. 35, p. 83-102, 2010.

VEGA, Lope de. Parte veinte y tres de las comedias de Lope Félix de Vega Carpio. En Madrid: por María de Quiñones: a costa de Pedro Coello..., 1638.

Recebido: 29 de julio de 2016 Aprovado: 04 de septiembre de 2016

\section{Autora/Author:}

DAVINIA RODRÍGUEZ ORTEGA < davinia.rodriguez.ort@gmail.com>

- Profesora en la Universidad Internacional de La Rioja (UNIR, España). Doctora en Filología Hispánica por la Universidad de Navarra. Campos de estudio: teatro Siglo de Oro, autos sacramentales, Calderón de la Barca, Lope de Vega, ediciones críticas, historia de la imprenta.

- Professora na Universidad Internacional de La Rioja (UNIR, Espanha). Doutora em Filologia Hispânica pela Universidad de Navarra. Campos de estudo: teatro do Século de Ouro, autos sacramentais, Calderón de La Barca, Lope de Vega, edições críticas, história da imprensa.

- Professor at the Universidad Internacional de La Rioja (UNIR, Spain). PhD in Philology from the Universidad de Navarra. Fields of study: Golden Age theater, sacramental plays, Calderon de la Barca, Lope de Vega, critical editions, history of printing. 